\title{
Significance of Teaching the Pronunciation of Segmental and Suprasegmental Features of English
}

\author{
Lok Raj Sharma \\ lokraj043@gmail.com \\ Lecturer \\ Makawanpur Multiple Campus, Hetauda, Nepal
}

\begin{abstract}
Pronunciation is an essential and rudimentary facet of language involved in an oral communication. This article attempts to highlight the significance of teaching the pronunciation of segmental and suprasegmentalfeatures of English. The segmentalfeatures involve consonant and vowel sounds or phonemes, whereas the suprasegmental features include stress, rhythm, intonation, pitch, length etc. The central function of a language is for communication through speech. The speech is sequences of the pronunciation of segmental as well as suprasegmental features. At least, legible pronunciation is essential for an understandable communication. Legible pronunciation of any one of Standard British English (SBE), Scottish Standard English and General American English (GAE) is indispensable for the proper and effective oral communication in the global context. Standard British English (SBE) is normally used in context of teaching English to the students in Nepal. It is a difficult task to teach the standard pronunciation to the students whose native tongue is not English, but teaching pronunciation can improve their ways of speaking to some extent. There is not always one-to-one corresponding correlation between spellings and their sounds in words. A spelling may retain different sounds in different phonetic environment. The article writer has pinpointed some instances where the wrong pronunciation of a speaker can lead to a misleading communication. To avoid the wrong or unintelligible pronunciation, it is necessary to teach the intelligible or standard pronunciation of English to our students.
\end{abstract}

Keywords: English, pronunciation, segmental, suprasegmental, teaching

\section{Introduction}

English is one of the global languages of communication, trade, education, literature, philosophy, diplomatic affair, science and technology. Huwari and Mehawesh (2015) regarding English language assert that "English language has become the language of choice in most countries around the world" (p.31). There are several varieties or accents of English spoken in various parts of the world. Giegerich (2009) has mentioned the three varieties of Standard English regarding vowel inventories. The three varieties are: Southern British Standard Vowel Phonemes (RP: Received Pronunciation), Scottish Standard English Vowel Phonemes (SSE) and General American Vowel Phonemes (GA). But we use the Classical System of English which includes 24 consonant phonemesand 20 vowel phonemes to teach the students in their early stage. Among 20 vowel phonemes, there are 12 monophthongs and 8 diphthongs. 
While speaking, we use both segmental features and suprasegmental features. The segmental features embrace consonant and vowel sounds or phonemes, whereas stress, pitch, intonation, length, juncture etc. are included in suprasegmental features. The suprasegmental features play a prominent role in determining the mood, sex, emotional state, gender and age of the speaker and the meanings of his / her utterances.

The article writer has mentioned 24 consonant phonemes, spellings that form the sounds and their position of occurrence in the words; and similarly 20 vowel sounds and spellings that form the sounds. The suprasegmental features of English are defined and dealt with in this article. More importantly, some instances or situations where bits of communication become misleading due to wrong or improper pronunciation are described to justify the significance of correct pronunciation. It is hoped that teaching pronunciation can improve the quality of communication.

\section{Significance of Teaching the Pronunciation of English}

Communication is a prime universal function of language. Errors in pronunciation results ina bad or puzzling communication. There is importance of teaching pronunciation for a successful communication. Communication at least must be intelligible. Kelly (2006, pp.11-13) mentions that teaching pronunciation helps in communication by helping in: communication of meaning, communication of function and communication of mood and attitude. The teaching of pronunciation is important for improving language skills and for developing linguistic awareness. Tudor (2001) opines that "command of phonology of a language can play an important affective role in language use" (p. 53). Such command can be enhanced through teaching and persistent practice. Similarly, Setter and Jenkins (2005) also contend that pronunciation "plays a vital role in successful communication both productively and receptively" (p. 2).Celce-Murcia, Brinton and Goodwin (1996) state that "intelligible pronunciation is one of the necessary components of oral communication" (p. 8). Teaching pronunciation provides the students with basic idea about intelligible pronunciation of segmental and suprasegmental features resulting in a intelligible communication. Teaching the pronunciation of English develops confidence in students to speak in English wherever they go. Fraser (2000) remarks that "with good pronunciation, a speaker is intelligible despite other errors; with poor pronunciation, a speaker can be very difficult to understand, despite accuracy in other areas" (p.7). Hammond (1995) contends that "we must also take into account the importance of handling both sound and meaning in the pursuit of the linguistic goals of our students" (p.294). Robertson (2003) believes that "intelligible pronunciation is an essential component of communicative competence" (p. 4).Varasarin (2007) affirms that "one of the prominent and promising outcomes of a good pronunciation is the feeling of self-confidence since poor pronunciation degrades good language skills and condemns learners to less than their deserved social, academic and work advancement" (p.45).Teaching pronunciation enhances their speaking skills and ultimately their personality.

\section{Theoretical Review of Literature Segmental Features}

All the consonant and vowel phonemes are segmental features. They refer to discrete units that can be identified physically or auditorily in the stream of speech of any language. 


\section{Consonant Sounds}

Consonant sounds are those speech sounds for the production of which there is a sort of obstruction in the vocal tract. Crystal (2003) asserts that Consonants are "sounds made by a closure or narrowing in the vocal tract so that the airflow is either completely blocked, or so restricted that audible friction is produced" (p.103). It means consonant sounds are produced when there is an obstruction of the airflow somewhere in the vocal tract. Connor (2000) contends that "consonants are generally made by a definite interference of the vocal organs with the air stream, and so are easier to describe and understand" (p.24). Similar view is expressed by Verma and Krishnaswamy (1999) who consider a consonant as "a sound characterized by constriction accompanied by some measure of friction or closure followed by release" (p.35). Hyman (1975) emphasizes that "a language learner must master the production and perception of the sounds of a given language" (p.1). His assertion focuses on the importance of learning sounds. There are 24 consonant sounds of English. They are presented with spellings and words in the table given below.

Table 1: Correlation between consonant spellings and sounds

\begin{tabular}{|c|c|c|c|c|c|}
\hline S.N & Sound & Spellings & Initial Position & Medial Position & Final Position \\
\hline 1. & $/ \mathrm{P} /$ & $\mathrm{p}, \mathrm{pp}$ & pat, pun, pat & apple, apes & cap, up, rope, jump \\
\hline 2. & $/ \mathrm{b} /$ & $\mathrm{b}, \mathrm{bb}$ & bat, but & cabbage, rubs & rob, rub, sob \\
\hline 3. & $/ \mathrm{t} /$ & $\mathrm{t}, \mathrm{tt}$, th, ed & tune, Thomas & cattle, cats, & but, hoped, laughed \\
\hline 4. & $/ \mathrm{d} /$ & $\mathrm{d}, \mathrm{dd}$ & do, deed, dance & lads, bladder & lad, glad, shade, sad \\
\hline 5. & $/ \mathrm{k} /$ & $\mathrm{k}, \mathrm{c}, \mathrm{ck}, \mathrm{ch}, \mathrm{q}, \mathrm{cc}$ & kid, can, chorus, quit & looks, locks, soccer & lake, luck, music \\
\hline 6. & $/ \mathbf{g} /$ & g, gg, gh & go, get, ghost & leg, baggage & leg, mug, log, hog \\
\hline 7. & It $\int 1$ & ch, tch, tu, & child, chop & benches, butcher, future & beach, match, bitch \\
\hline 8. & $/ \mathrm{d} \mathbf{3} /$ & j, dge, g, ge,di, de & jug, gin, gentle & Ages, soldier, grandeur & edge, large, age, \\
\hline 9. & $/ \mathrm{m} /$ & $\mathrm{m}, \mathrm{mm}$ & man, meet & summon, comes & sum, some, come \\
\hline 10. & $/ \mathbf{n} /$ & $\mathrm{n}, \mathrm{nn}, \mathrm{gn}$ & now, gnat, gnaw & hand, manner & can, ban, man, then \\
\hline 11. & $/ n \mid$ & $\mathrm{n}, \mathrm{ng}$ & & rank, tank, kings & sing, ring, king, spring \\
\hline 12. & $/ \mathrm{f} /$ & $\mathrm{f}, \mathrm{ff}, \mathrm{ph}, \mathrm{gh}$ & fan, phone, & suffer, lift & leaf, staff, rough, off \\
\hline 13. & $\mid \mathbf{v} /$ & $v, f$ & van, vote & leaves, lives & love, live, of, leave \\
\hline 14. & $|\theta|$ & th & thin, thank & months, method & cloth, path, bath \\
\hline 15. & $|\partial|$ & th & that, this, there & mother, father & bathe, clothe \\
\hline 16. & $|\mathrm{~s}|$ & $\mathrm{s}, \mathrm{ss}, \mathrm{sc}, \mathrm{c}$ & sun ,scene, sentre & fast, bosses, & bus, glass, place, race \\
\hline 17. & $|z|$ & $z, z z, s, x$ & zebra, zero, Xerox & puzzle, nuzzle & buzz, girls, topaz \\
\hline 18. & $/ \mathrm{S} /$ & sh, s, ssio, tio, tia, ch & she, sure, chef & worship, mission, initial, motion & wash, bush, push, \\
\hline 19. & $|3|$ & sio, sure, g & genre, jabot & division, measure & garage, beige, rouge \\
\hline 20. & $/ \mathrm{h} /$ & $\mathrm{h}$, wh & home, how, who & behind, behave & \\
\hline 21. & $|r|$ & $\mathrm{r}, \mathrm{Ir}, \mathrm{wr}$ & rat, wnite & spring, cany & \\
\hline 22. & $/ \mathrm{j} /$ & $y, u$, ew, ue & yes, yak & fuse, value, new & \\
\hline 23. & $/ \mathrm{w} /$ & w, wh, qu & was, what & swim, queen & \\
\hline 24. & $/ 1 /$ & 1,11 & love, like & girls, falls, pulse & tall, hall, real, fill \\
\hline
\end{tabular}


This table clearly shows that some sounds occur in the three positions of words, some sounds do not occur in the word- final position, and one sound namely, / $\mathrm{y} /$ does not occur in the wordinitial position.

\section{Vowel Sounds}

Vowels are the speech sounds which are produced without any sort of obstruction in the vocal tract. They are the peaks of syllables.Crystal (2003) asserts that vowels are "sounds articulated without a complete closure in the mouth or a degree of narrowing which would produce audible friction" (p.517). It means vowel sounds are produced with a friction of the airflow in the vocal tract. Therefore, they are voiced. Connor (2000) affirms that "vowels are made by voiced air passing through different mouth shapes; the differences in the shape of the mouth are caused by different positions of the tongue and of the lips" (p.79). Similar view is expressed by Verma and Krishnaswamy (1999) who consider a vowel as "a sound produced by the unobstructed passage of the airstream" (p.34). The similar concept is expressed by Roach (2000) who states that "vowels are sounds in which there is no obstruction to the flow of air as it passes from the larynx to the lips"(p. 10). Vowels are voiced sounds. There are 20 vowel sounds of English.They are categorized into two types: monophthongs and diphthongs. They are presented with spellings and words in the table given below.

Table 2: Correlation between monophthongs and spellings

\begin{tabular}{|c|c|c|c|}
\hline S.N. & Sounds & Spellings & Words \\
\hline 1. & $/ x /$ & $\overline{i, y, u i}$ & big, pity, build \\
\hline 2. & $/ \mathbf{i}: 1$ & ee, ea, ie, ei & bee, sea, field, receive \\
\hline 3. & 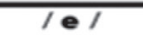 & e, ea & pen, head, deaf \\
\hline 4. & $/ \infty 1$ & $\overline{\mathbf{a}}$ & at, land, sad, pan \\
\hline 5. & 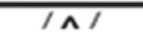 & $\mathbf{u , o u}$, & cup, country \\
\hline 6. & 101 & a, er, or, our, & ago, father, doctor, colour, \\
\hline 7. & /a: / & $\overline{i r}, \mathbf{u r}, \mathbf{w o r}$ & bird, burn, word \\
\hline$\overline{8 .}$ & /a: / & a, al, as & after, calf, last \\
\hline 9. & $/ \mathrm{DI}$ & $\overline{\mathbf{o}, \mathbf{o u}}$ & hot, cough \\
\hline 10. & /0: / & or, au, aw, & for, cause, drav \\
\hline 11. & $/ \boldsymbol{I U 1}$ & u, ould & put, could, would \\
\hline 12. & / u: / & 00 , ue, evv & moon, blue, chew \\
\hline
\end{tabular}

Monophthongs are termed as pure or single vowels which are produced without a noticeable change in vowel quality. 
Table 3: Correlation between diphthongs and spellings

\begin{tabular}{|c|c|c|c|}
\hline S.N. & Sounds & Spellings & Words \\
\hline 1. & / er / & ai, ay, a-e & pain, day, make, pane \\
\hline 2. & / ar / & ie, y, uy, igh & die, by, buy, high \\
\hline 3. & / or / & oi, oy, awi & old, boat, blow, soul \\
\hline 4. & / ov / & o, oa, ow, ou & Out, about, cow, how \\
\hline 5. & / au / & ou, ow & hear, deer, fierce \\
\hline 6. & / rə / & ear, eer, ier & air, fair, care, share \\
\hline 7. & / eə / & air, are & moor, tour, cure, sure \\
\hline 8. & / və / & oor, our, ure & \\
\hline
\end{tabular}

Diphthongs as speech sounds involve two vowels. They glide from one vowel to another one, and the whole glide acts like one vowel sound. There is a noticeable change in the quality of vowel when we pronounce them.

\section{Suprasegmental Features}

Supra-segmental features are those features of speech which extend over more than a single sound in an utterance. They make use of parameters of loudness, pitch, juncture and duration. Supra-segmental features have distinctive roles in a language to distinguish meanings, moods and senses of utterances. Ladefoged (2006) defines suprasegmental features as "those aspects of speech that involve more than single consonants or vowels" (p.237). The principal types of supra-segmental features to be dealt in this article are:

Length: Length of a sound is the duration or period of time taken to its articulation. Length is the quality of vowel in most of languages. Jones (1979) considers length as "the length of time during which it is held on continuously in a given word or phrase" (232), for example, / $\square /$ is a short vowel and / i: / is a long vowel. They create different meanings in the words. /s $\square \mathbf{t} /$ is the phonemic transcription of the word "sit" (to take a seat), and / si:t /is the phonemic transcription of the word "seat" (a place to sit).

Stress: Stress is an extra force used in pronouncing a syllable. It is the degree of loudness, tenseness, sonority and muscular energy used while pronouncing a particular syllable. Jones (1979) describes stress as "the degree of force with which a sound or syllable is uttered" (p.245). Gimson (1990) affirms that "the number of syllables stressed by the speaker depends largely upon the nature of words composing the utterance "(p.263). Cross (1992) defines stress as "the articulation of a syllable with greater emphasis, or more force than others" (p.224). Stress plays a distinctive (phonemic) role in English. The place of stress in the same words suggests different meanings and parts of speech. 
Intonation: Intonation is defined as the linguistic use of pitch at a sentence level. The rise or fall of pitch in the utterance of a phrase or sentence is called intonation. It is the quality of an utterance. Harmer (1990) considers intonation as "the music of speech" (p.11). Kelly (2006) defines intonation as "the way voice goes up and down in pitch when we are speaking" (p.86).

Juncture: Juncture is a phonetic boundary between phonemes or syllables. This is related to the proper pausing while speaking. Carr (2008) opines juncture as "a boundary or transition point in a phonological sequence" (p.81). Trask (2005) asserts that "juncture is any phonetic feature whose presence signals the existence of a grammatical boundary" (p.189). The same phonological utterance may have different meanings due to pausing in different places. Examples: /ən-e $\square \mathbf{m} /$. Thepause after "n" forms a phrase "an aim", and / $\boldsymbol{\jmath}-\mathbf{n e} \square \mathbf{m} /$ in which the pause occurs after "a" constructs a phrase "a name".

Pitch / Tone: The pitch of a sound is an auditory property that enables a listener to place it on a scale going from low to high, without considering its acoustic properties. Crystal (2003) defines pitch as "the attribute of auditory sensation in terms of which a sound may be ordered on a scale from low to high" (355). Ladefoged (1982) asserts that "pitch variations that affect the meaning of a word are called tones" (227). Richards, Platt and Platt (1999) define tone as "height of pitch and change of pitch which is associated with the pronunciation of syllables or words, and which affects te meaning of the words" (382). The variation in pitch may give different kinds of information such as gender, the age of the speaker, the emotional states of the speaker and meanings of words.

\section{Pronunciation}

Oxford Dictionary of English (2003)defines pronunciation as "the way in which a word is pronounced" (p.1410). Harmer (2008) asserts that "English pronunciation causes many problems due to lack of sound spelling correlation in it" (p.250). Kelly (1969) regards pronunciation as the "Cinderella of language teaching" (p. 87). Zuengler (1988) clearly states that "pronunciation is a domain within which one's identity is expressed" (p. 34). Block (2007) defines identities as "socially constructed, self-conscious, ongoing narratives that individuals perform, interpret and project in dress, bodily movements, actions and language" (p. 27). Pronunciation depicts the speech personality of a person.

\section{Teaching}

Teaching is a transmission of knowledge to bring a remarkable change at the understanding level of learners on particular subject matters. It is an intricate task. The subject teacher must be resourceful for teaching. The students should be motivated towards learning pronunciation. Fraser (1999) advises the teachers to realize that as with segmentals, "the learners actually hear speech very differently than the teachers themselves do" (p. 4). That's why the teacher should have clear voice to teach sounds. Macdonald (2002) expresses the bitter reality that "teachers intentionally skip pronunciation because they lack confidence, skills and knowledge" (p.3). On the other hand, Goswami (1993) assumes that "dyslexic children (children with reading difficulties) cannot use orthographic analogies as a reading strategy since they lack the phonological knowledge 
necessary to use similarities in spelling patterns as a basis for making predictions about shared sound" (p. 307).

The article writer recommends the teachers to use the analytic-linguistic approach to teach segmental features and the integrative approach to teach suprasegmental features. The analytic-linguistic approach uses the charts of vocal tracks, the phonetic alphabet in imitation, listening, and production as supplementary materials. In this approach, the teachers should make clear different aspects of pronunciation such as the position of the tongue, manner of articulation and place. The integrative approach mainly focuses on rhythm, intonation, stress etc. as it is necessary to practise them in a discourse beyond the word level and phoneme.

\section{Methodology}

This article is based on a qualitative descriptive research design which employs the categorical data.

\section{Population}

Segmental and suprasegmental features work as the population or universe of the study.

\section{Sampling design and sample size}

The researcher followed the purposive sampling design to select the sample size.

Segmental features which include twenty-four consonant phonemes and twenty vowels phonemes along with suprasegmental features which comprise length, intonation, pitch, and juncture are taken as a sample for the study.

\section{Tools of data collection}

The researcher noted down the points or conditions where students face difficulty in pronunciation work as tools for collecting the research data. Such points or conditions were taken from the related books and journal articles of English regarding pronunciation. Such relevant books and articles teach us the standard pronunciation of English.

\section{Analysis of Data}

The qualitative data namely, categorical data are pinpointed and exemplified for analysis. The analysis spotlights the students' problems with pronunciation and provides instruction for the standard pronunciation.

\section{Ethical Issue}

The researcher has presented his own examples experienced in the teaching learning activities, and has cited the previous writers in this article for maintaining ethical codes. 


\section{Presentation and interpretation of qualitative data}

Teaching the pronunciation of segmental and suprasegmental features of English is a crucial task that helps the learners produce intelligible pronunciation for the communication. The points of difficulty in pronunciation work as the qualitative data.

There are certain points or situations where students have problems with pronunciation. One of the problems or difficulties arises because of the fact that there is no always corresponding correlation between spellings and their sounds. Spelling is an integral part of writing and a significant cause of pronunciation errors. Kelly (2000) assumes that"English spelling is not as irregular as it seems" (p. 123).

\section{Point 1: Pronunciation of phonemes of consonant spellings}

Teachers need to tell students that a single consonant spelling may be realized by different phonemes as depicted in the following table.

Table 4: Single consonant spellings and their sounds

\begin{tabular}{|c|c|c|}
\hline S.N. & Spelling & Sounds in the words \\
\hline 1. & $\mathbf{c}$ & $\mathrm{k} /$ in cat, cop, cup; / $\mathrm{s} /$ in center, city and $/ \mathrm{t} \int /$ in cello, cellist etc. \\
\hline 2. & $\mathbf{g}$ & $/ \mathrm{g} /$ in get, god; $/ \mathrm{d}_{3} /$ in gene, gem and $/ 3 /$ in genre, rogue etc. \\
\hline 3. & $\mathbf{n}$ & $/ \mathrm{n} /$ in name, can, mind and $/ \mathrm{n} /$ in tank, monkey etc. \\
\hline 4. & $\mathrm{~s}$ & $/ \mathrm{s} /$ in sit, seat $; / \int /$ in sugar, sure and $/ 3 /$ in measure, division etc. \\
\hline 5. & $\mathbf{x}$ & / ks / as in ox, fox;/z/in Xerox, xylophone; / / in Xian and/s / in Xu. \\
\hline 6. & f & $/ \mathrm{f} /$ in $\mathrm{fan}, \mathrm{far}$, leaf and $/ \mathrm{v} /$ in of etc. \\
\hline
\end{tabular}

This table obviously demonstrates that a spelling has manifold forms of pronunciation in English.

\section{Point 2: Pronunciation of phonemes of consonant spellings}

Two spellings forming a sound are called a diagraph, and the same diagraph may be realized by different sounds as shown in the following table.

Table 5: Double consonant spellings and their sounds

\begin{tabular}{|c|c|c|}
\hline S.N. & Spelling & Sounds in the words \\
\hline 1. & cc & $\mathrm{k} /$ in soccer, occur and $/ \mathrm{ks} /$ in accent, success etc. \\
\hline 2. & ch & $\mathrm{k} /$ in choir, monarch; / $\mathrm{t} /$ in chair, beach and $/ \mathrm{S} /$ in chef, chic etc. \\
\hline 3. & gg & $/ \mathrm{g} /$ in beggar, shaggy and $/ \mathrm{d}_{3} /$ in suggest, suggestion etc. \\
\hline 4. & gh & $/ \mathrm{f} /$ in laugh, rough and $/ \mathrm{g} /$ in ghost, ghee etc. \\
\hline 5. & th & $/ \theta /$ in bath, thin $; / \partial /$ in there, this and $/ \mathrm{t} /$ in Thailand, Thomas etc. \\
\hline 6. & wh & $/ \mathrm{w} /$ in what, why, when, and $/ \mathrm{h} /$ in who, whose etc. \\
\hline
\end{tabular}


Significance of Teaching the Pronunciation of Segmental... / 71

This table shows that a diagraph may have a single consonant sound or two consonant sounds.

Point 3: Pronunciation of phonemes of consonant spellings that function as inflectional suffixes

Almost all the students or speakers make mistakes in pronouncing inflectional suffixes. It is a necessary step to teach them this pronunciation. Students are required to learn the following rules:

1. $/ \mathrm{p} /, / \mathrm{t} /, / \mathrm{k} /, / \mathrm{f} /, / \theta /, / \mathrm{s} /, / \int /, / \mathrm{t} \int /$ and $/ \mathrm{h} /$ are voiceless consonants. The suffix's' is pronounced $/ \mathrm{s} /$ after voiceless consonants other than $/ \mathrm{s} /, / \mathrm{S} /, / \mathrm{t} \int /$ and $/ \mathrm{h} /$ as in:

caps / kæps /, beats / bi:ts /, books / buks /, laughs / la:fs /, months / man $\theta$ s /, cat's / kæets /

2. $/ \mathrm{b} /, / \mathrm{d} /, / \mathrm{g} /, / \mathrm{d}_{3} /, / \mathrm{m} /, / \mathrm{n} /, / \mathrm{g} /, / \mathrm{v} /, / \mathrm{d} /, / \mathrm{z} /, / 3 /, / \mathrm{r} /, / \mathrm{j} /, / \mathrm{w} /$ and $/ 1 /$ are voiced consonants. The suffix's' is pronounced $/ z /$ after voiced consonants other than $/ \mathrm{d}_{3} /, / z /, / 3 /, / \mathrm{r} /, \mathrm{j} /$, and $/$ w/. For example:

verbs / va:bz/, builds / brldz/, bags / bagz/, lives/livz/, $\mathrm{rams} / \mathrm{ramz} /$, pens $/$ penz

Kings / kinz/, balls / bo:lz /, clothes / kəuðzz/, man's / mænz /

Note: Sounds $/ \mathrm{r} /, \mathrm{j} /$, and $/ \mathrm{w} /$ do not occur at the end of the words, but letters may occur and they may work or support vowel sounds.

3. The suffix ' $s$ ' is pronounced $/ z /$ after the vowels that are also voiced sounds. The spellings ' $w$ ' and ' $y$ ' at the end of the words do not work as the consonant sounds. They work as vowel sounds. The spelling ' $r$ ' at the end of word in isolation remains silent as in:

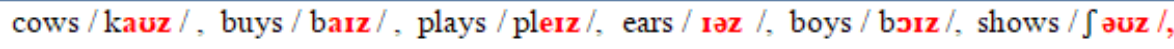
bees / bi:z /, cars / ka:z/, cow's/kauz/, goes/gəuz/

4. The spellings 'es' is pronounced / $\mathrm{Iz} /$ after the consonant sounds $/ \mathrm{d}_{3} /, / \mathrm{z} /, / 3 /, / \mathrm{s} /, / \mathrm{S} /$ and $/ \mathrm{t} \int /$. For example:

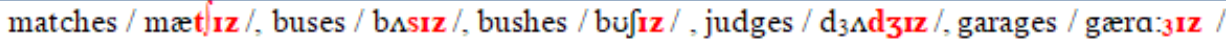
buzzes / baz IZ/ 
$5 . / \mathrm{b} /, / \mathrm{d} /, / \mathrm{g} /, / \mathrm{d} 3 /, / \mathrm{m} /, / \mathrm{n} /, / \mathrm{g} /, / \mathrm{v} /, / \mathrm{d} /, / \mathrm{z} /, / 3 /, / \mathrm{r} /, / \mathrm{j} /, / \mathrm{w} /$ and $/ 1 /$ are voiced consonants. The suffix 'ed' is pronounced / $/$ after voiced consonants other than $/ \mathrm{d} /$ as in:

rubbed $/ \mathrm{rabd} /$, begged / begd /, lived / livd /, summed / s smd /, banned / bæend/, ringed $/$ rind/, called / ko:ld /, judged $/ \mathrm{d}_{3} \Lambda \mathrm{d}_{3} \mathrm{~d} /$, breezed/bri:zd/, garaged / gæra: ${ }_{3} \mathrm{~d} /$

6. The spelling 'ed' is pronounced /d/after vowel sounds. It is to remember that the spellings ' $w$ ' and ' $y$ ' at the end of the words remain silent or work as vowel sounds. For example:

rowed / kaud / (noise), lied / lard/, played / pleid/, sawed/s s:d / (cut),employed / mplord/ , showed / Saud/

7. $/ \mathrm{t} /, / \mathrm{k} /, / \mathrm{f} /, / \theta /, / \mathrm{s} /, / \mathrm{S} /, / \mathrm{t} \int /$ and $/ \mathrm{h} /$ are voiceless consonants. The suffix 'ed' is pronounced / $t /$ after voiceless consonants other than $/ t /$ as in:

helped / helpt /, looked / lukt /, laughed / la:ft /, missed / mist /, pushed / puft /, watched / wo:tst /

8. The spelling 'ed' is pronounced / Id / after $/ \mathrm{d} /$ and $/ \mathrm{t} /$. For example:

wanted /wontıd/, fainted /femtıd/, needed/ni:dıd/, heeded / hi:dıd/

\section{Point 4: Pronunciation of words with silent spellings}

Teachers are required to teach the students that some letters are silent in the certain words. It means some spellings of the certain words are not pronounced as shown in the table given below.

\begin{tabular}{|l|l|}
\hline Silent Letters & \multicolumn{1}{|c|}{ Words } \\
\hline b & $\begin{array}{l}\text { Aplomb, Bomb, Climb, Comb, Coulomb, Crumb, Debt, Doubt, Dumb, Jamb, } \\
\text { Lamb, Limb, Numb, Plumber, Subtle, Succumb, Thumb, Tomb, Womb... }\end{array}$ \\
\hline c & $\begin{array}{l}\text { Ascend, Ascend, Ascent, Conscience, Conscious, Crescent, Descend, Disciple } \\
\text { Fluorescent, Muscle, Obscene, Scenario, Scene, Scent, Science. Scissors... }\end{array}$ \\
\hline d & Badge, Edge, Handkerchief, Handsome, Hedge, Sandwich, Wedge, Wednesday.... \\
\hline g & $\begin{array}{l}\text { Align, Assign, Benign, Campaign, Champagne, Cologne, Consign, Design, Feign, } \\
\text { Foreign, Gnarl, Gnarly, Gnat, Gnaw, Gnome, Reign, Resign, Sign... }\end{array}$ \\
\hline h & $\begin{array}{l}\text { Ache, Choir, Chord, Choreograph, Chrome, Echo, Ghost, Heir, Honest, Hour, } \\
\text { Rhythm, Scheme, School, Stomach, Tech, What, Which, While, White, Why .... }\end{array}$ \\
\hline k & $\begin{array}{l}\text { Knack, Knead, Knee, Kneel, Knew, Knickers, Knife, Knight, Knitting, Knob, } \\
\text { Knock, Knot, Know, Knowledge, Knuckle... }\end{array}$ \\
\hline n & $\begin{array}{l}\text { Almond, Balm, Calf, Calm, Chalk, Could, Folk, Half, Palm, Salmon, Should, Talk, } \\
\text { Walk, Would, Yolk... }\end{array}$ \\
\hline p & Autumn, Column, Damn, Hymn... \\
\hline s & $\begin{array}{l}\text { Coup, Cupboard, Pneumonia, Pseudo, Psychiatrist, Psychic, Psychology, } \\
\text { Psychotherapy, Psychotic, Raspberry, Receipt... }\end{array}$ \\
\hline t & Aisle, Island, Patios... \\
\hline w & $\begin{array}{l}\text { Apostle, Bristle, Bustle, Butcher, Castle, Christmas, Fasten, Glisten, Hustle, Listen, } \\
\text { Match, Moisten, Scratch, Soften, Thistle, Watch, Whistle, Witch, Wrestle... }\end{array}$ \\
\hline & $\begin{array}{l}\text { Answer, Awry, Playwright, Sword, Two, Whole, Wrack, Wrap, Wrapper, Wrath, } \\
\text { Wreath, Wreck, Wrench, Wrestling, Wretched, Wrinkle, Wrist, Wrong, Wrote.... }\end{array}$ \\
\hline
\end{tabular}


This table presents only some words whose spellings are silent. The silent spellings may occur in the initial position, medial position and the final position of the words.

\section{Point 5: Pronunciation of phonemes of vowel spellings}

Pronunciation of vowel spellings is more difficult and more puzzling than that of the consonant spellings. A vowel can form diverse segments of pronunciations in different words as shown in the following table.

Table 7: Single vowel spellings and their sounds

\begin{tabular}{|c|c|c|}
\hline S.N. & Spelling & Sounds in the words \\
\hline 1. & a & $\begin{array}{l}/ \mathfrak{a} /, / \mathbf{e} /, / \mathbf{a}: /, / \mathbf{v} /, / \mathbf{\jmath}: /, / \mathbf{a} /, / \mathbf{I} / \text { and / er / in the words 'act', 'many', } \\
\text { 'bath', 'what', 'ball', 'about', 'village' and 'apron' respectively. }\end{array}$ \\
\hline 2. & e & $\begin{array}{l}\text { /e/,/I/,/ / / and /i: // in the words 'pen', 'exam', 'father' and 'she' } \\
\text { respectively. }\end{array}$ \\
\hline 3. & $\mathrm{i}$ & $\begin{array}{l}/ \mathbf{I} /, / \mathrm{i} /, / \text { / / and / ar / in the words 'fill', 'machine', 'quality' and 'kind' } \\
\text { respectively. }\end{array}$ \\
\hline 4. & o & $\begin{array}{l}/ \mathbf{v} /, / \mathbf{v} /, / \mathbf{u}: /, / \mathbf{\Lambda} /, / \text { ə / and / əu / in the words 'hot', 'wolf', 'do', } \\
\text { 'come', 'obey', and 'go' respectively. }\end{array}$ \\
\hline 5. & $\mathbf{u}$ & $\begin{array}{l}\text { pronounced / } \mathbf{\Delta} /, / \mathbf{v} / \text { and / e / in the words 'cut', 'full' and 'bury' } \\
\text { respectively }\end{array}$ \\
\hline
\end{tabular}

This table exhibits that a vowel spelling may have more than two vowel phonemes in the words.

Point 5: Pronunciation of phonemes of double vowel spellings

Students have serious problems with pronouncing vowel phonemes of double spellings as mentioned in the following table. 
Table 8: Double vowel spellings and their sounds

\begin{tabular}{|c|c|c|}
\hline S.N & Spellings & Sounds in the words \\
\hline 1. & ai & / e/,/ æe/,/ er / and / ea / in the words 'said', 'plaid', 'fail' and 'fair' respectively. \\
\hline 2. & au & / a:/, v/,/ כ: / and / er/ in the words 'laugh', 'because', 'caught' and 'gauge' respectively. \\
\hline 3. & ay & / i: /, / I / and / er / in the words 'quay', 'Sunday' and 'day'respectively. \\
\hline 4. & ea & /i:/,/ rə /, /e/,/ eə / and/er/ in the words 'sea', 'clear', 'head', 'bear' and 'break' respectively. \\
\hline 5. & ee & /i: /and / ra / in the words 'see' and 'deer' respectively. \\
\hline 6. & ei & / er/,/ar/,/i: / and / ea/in the words 'veil', 'either', 'receive' and 'their' respectively. \\
\hline 7. & eo & / i: / and / / / in the words 'people' and 'pigeon' respectively. \\
\hline 8. & eu & / ü: / and / $\mathbf{r}$ // in the words 'feud' and 'museum' respectively. \\
\hline 9. & ey & / i: / and / er / in the words 'key' and 'they'respectively. \\
\hline 10. & ie & / $\mathbf{1}$ /,/ ar / and / / / in the words 'fierce', 'die' and 'friend' respectively. \\
\hline 11. & oe & / $2 \mathbf{u} /, / / \mathbf{u}: /$ and / $\mathbf{\Delta} /$ in the words 'foe', 'shoe' and 'does' respectively. \\
\hline 12. & oo & / u:/,/u/,/ / / and / $\mathbf{v}$ / in the words 'moon', 'good', 'flood' and 'poor' respectively. \\
\hline 13. & ou & $/ \mathbf{a v} /, / \mathbf{u}: /, / \mathbf{\Lambda} /, \mathbf{v} /$ and / əu / in the words 'out', 'group', 'country', 'could' and 'soul' respectively. \\
\hline 14. & ow & / au / and / ou / in the words 'cow' and 'know' respectively. \\
\hline 15. & ue & / u: / and / uə / in the words 'blue' and 'influence'respectively. \\
\hline
\end{tabular}

This table displays that double vowel spellings form two or more vowel phonemes in the words.

\section{Point 6. Pronunciation of phonemes in connected speech}

Assimilation is a phonological process which involves the change of one sound into another due Ten bikes [tembarks] (/ $\mathrm{n} /$ changes into $[\mathrm{m}]$ which is alike $[\mathrm{b}]$ of the next word because both are bilabial.

Good boy [gubbri] (/d / changes into [b] which is identical with the neighbouring sound.)

Could you? [Kudzu] (/d/and / $/$ / are fused to produce [d3]).

\section{Point 7. Pronunciation of the spelling ' $r$ '}

Students are often confused with the pronunciation of the spelling ' $r$ '. The rules for pronouncing or not pronouncing ' $r$ ' are given below:

i. ' $r$ ' in the word final position is not pronounced as in:

$$
\text { Pear/pea/deer / dia/doctor/dokta/ }
$$

ii. ' $r$ ' followed by a consonant sound is not pronounced as in:

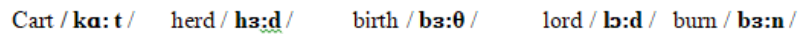

iii. ' $r$ ' followed by a consonant sound in connected speech is not pronounced as in:

Your cap/jo: kæep/ water tank/wo:tə tåk/ bigger book /rgəbuk/

iv. ' $\mathrm{r}$ ' followed by a vowel sound is pronounced as in:

Ran /raen / strength/stren $\boldsymbol{\theta}$ / spring/sprin/ strong/stroy/ $\mathrm{rum} / \mathrm{ram} /$

v. ' $r$ ' followed by a vowel sound in connected speech is pronounced as in:

Your arm/jə: $\mathbf{r} \mathbf{a}: \mathbf{m}$ / car arrived/kar ərarvd/ pair of / peər əv / 


\section{Point 8. Pronunciation of the words with vowels}

Almost all the students pronounce the words 'fill' and 'feel' as /frl/, 'pull' and 'pool' as /pul/, 'pen' and 'pain' as /pen/, 'let' and 'late' as/let/, 'beer' and 'bear' as /bra/ etc. It makes speech confusing. The teacher should teach the students that these words have different pronunciation.

Fill / frl/ feel/fill/ pull / pul/ pool / pu:l/ pen/pen/pain / pein/

let /let/ late/leit/ bear/bea/ beer/bra/ etc.

What will a native speaker understand if we say: How are you/frlın/now in place of / fi:lın/?,

and we can find a black animal called / bra/ in this forest in place of /ber/?

\section{Point 9. Problems of students with stress}

In disyllabic words, the stress, in general, falls on the first syllable if they are nouns or adjectives, but on the second syllable if they are verbs.

$$
\begin{array}{llll}
\text { 'INcrease (noun) } & \text { in'CREASE (verb) } & \text { 'EXport (noun) } & \text { ex'PORT (verb) } \\
\text { 'PREsent (adjective) } & \text { pre'SENT (verb) } & \text { 'ABsent (adjective) } & \text { ab'SENT (verb) }
\end{array}
$$

Stress is also important in sentences. It can suggest a different meaning on the basis of stressed words as in:

She is the 'ENGLISH 'TEACHER. (The teacher from England)

She is the 'ENGLISH teacher. (The teacher who teaches English)

I can 'RUN. (I am probably only telling you about my ability to run.)

I 'CAN run. (I am probably stressing the word 'can' because someone has suggested that I am not able to run and I am vehemently denying it.)

Is this your 'PENCIL? (A simple question with no deep meaning)

Is this 'YOUR pencil? (He might be showing by stress the word 'your' that there was something

\section{Point 10. Pronunciation of intonation}

Intonation is very important in spoken language and the native speaker uses it to create the desired effect or meaning. Roach (2001) defines intonation as "the melody of speech and is to be analyzed in terms of variations in pitch" (p.33). A sentence may have multiple meanings according to its tune shapes.O'Connor has identified four types of tune shape in English:

i. The falling tune ( the glide - down)

ii. The first rising tune ( the glide-up)

iii. The second rising tune ( the take-off)

iv. The falling -rising tune (the dive)

\section{Example: You will be late.}

- The meanings of this sentence can be explained differently based on its tune shape.

- If a speaker pronounces this utterance with the falling tune, it shows his general statement.

- If a speaker pronounces this utterance with the rising tune, it shows his intention of questioning. 
- If a speaker pronounces this utterance with the falling-rising tune, it shows his warning statement.

\section{Point 11: Pronunciation with juncture}

Students need to know where to pause while speaking. The pause determines the meaning as in:

\section{kaempəs /}

If we do not pause, the pronunciation shows a single word 'campus'.

If we pause after $/ \mathrm{m} /$, it shows us two words 'camp' and 'us'.

\section{/ aI-skri: m /}

If we pause after, $/ \square /$, it shows two words 'I' and 'scream'.

If we pause after /s/, it shows two words 'ice' and 'cream'.

Gilakjani and Ahmadi (2011) mention "accent, stress, intonation and rhythm, motivation and exposure, attitude, instruction, age, personality, and mother tongue influence" (p.81) as the factors that make pronunciation difficult to learn.

\section{Point 12. Pronunciation of pitch}

The meaning of a word depends the levels of pitch. For example, in Chinese language, /ma / has multiple meanings depending on the levels of pitch. Such a case can also be found in other languages.

$/ \mathbf{m} \square / \quad$ (High level tone): mother

(High rising tone): hemp

(Fallingtone): horse

(High falling tone): scold

\section{Conclusion}

Teaching the pronunciation of segmental and suprasegmental features is undoubtedly a challenging task for non-native speaker of English. Despite this challenging undertaking, teachers need to teach the pronunciation to students for the intelligible and fruitful oral communication. Gaining the intelligible pronunciation of English is possible through an intensive training or teaching in case of the students who learn English as a foreign language in spite of diverse points of difficulties regarding the pronunciation. The article writer has attempted to explore primarily 12 points based on his own teaching experience at the bachelor and master levels in the Faculty of Education. This article can be fruitful to students and teachers who are involved in teachinglearning the English language. 


\section{References}

Block, D. (2007). Second language identities. New York, NY: Continuum.

Carr, P. (2008). A glossary of phonology. Edinburgh: Edinburgh University.

Celce-Murcia, M., Brinton, D. M., \& Goodwin, J. M. (1996). Teaching pronunciation: A reference for teachers of English to speakers of other languages. New York, NY: Cambridge University Press.

Cross, D. (1992). A practical hand book to language teaching. New York: Prentice Hall.

Crystal, D. (2003). A dictionary of linguistics and phonetics. Oxford: Blackwell Publishing.

Fraser, H. (1999). ESL pronunciation teaching: Could it be more effective? Australian Language Matters, 7 (4). Retrieved on 14 May, 2020, from .

Fraser, H. (2000). Co-ordination improvements in pronunciation teaching for adult learners of English as a second language. Armidale: University of New England.

Giegerich, H.J. (2009). English phonology: An introduction. Cambridge: CUP.

Gilakjani, A. P.,\& Ahmadi, M. R. (2011). Why is pronunciation so difficult to learn? English Language Teaching, 4(3), 74-83.

Gimson, A.C. (1990). An introduction to the pronunciation of English (ELBS $4^{\text {th }}$ edition). Revised by Susan Ramsaran. London: English Language Book Society.

Goswami, U. (1993). Phonological skills and learning to read. New York: New York Academy of Sciences.

Hammond, R. M. (1995). Foreign accent and phonetic interference: The application of linguistic research to the teaching of second language pronunciation. Ed. Eckman, P. Second Language Acquisition: Theory and Pedagogy. Mahwah, NJ: Lawrence Erlbaum Associates.

Harmer, J. (1990). The practice of English language teaching. Harlow: Longman.

Harmer, J. (2008). The practice of English language teaching. Edinburgh Gate: Pearson Education Limited.

Huwari, I F., \& Mehawesh, M. (2015). Review of the importance of teaching pronunciation in the Arab society. International Journal on Studies in English Language and Literature, 3 (6), 31-37.

Hyman, L.M. (1975). Phonology: Theory and analysis. New York: Holt Rinehartand Winston.

Jones, D. (1979). Anoutline of English phonetics. Ludhiana: Kalyani Publishers.

Kelly, L. G. (1969). 25 centuries of language teaching. Rowley, MA: Newbury House.

Kelly, G. (2006). How to teach pronunciation. Delhi: Dorling Kindersley Pvt.Ltd.

Ladefoged, P. (2006). A course in phonetics. Boston: Thomson Wadsworth.

Macdonald, S. (2002). Pronunciation - views and practices of reluctant teachers. Prospect, 17(3), 3-18. 
O’Connor, J.D.(2000). Better English pronunciation. Delhi: CUP.

Roach, P. (2000). English phonetics and phonology. Cambridge: CUP.

Roach, P. (2001). Phonetics. Spain: Oxford University Press.

Robertson, P. (2003). Teaching English pronunciation skills to the Asian learner. A cultural complexity or subsumed piece of cake? Asian EFL Journal, 2,1-5

Setter, J., \& Jenkins, J. (2005). Pronunciation. Language Teaching, 38, 1-17.

Soanes, C., \& Stevenson, A. (Eds). Oxford dictionary of English (2 $2^{\text {nd }}$ ed.) New Delhi: Oxford University Press.

Trask, R. L. (2005). Dictionary of phonetics and phonology. New York: Taylor \& Francis Routledge.

Tudor, I. (2001). The dynamics of the language classroom. Cambridge: Cambridge University Press.

Varasarin, P. (2007). An action research study of pronunciation training, language learning strategies and speaking confidence. (Doctoral dissertation). Victoria University, Thailand.

Verma, S.K. \& Krishnaswamy, N. (1999). Modern linguistics. New Delhi: Oxford University Press.

Zuengler, J. (1988). Identity markers and L2 pronunciation. SSLA, 10,33-49. 